the phage (Table 2). From these data it follows that the hydration of DNA is much higher than the hydration of the protein part. Thus, the phage in water solutions, to a good approximation, may be considered as a homogeneous body at a resolution corresponding to several subsidiary maxima.

\section{Table 2. Parameters of $\mathrm{S}_{\mathrm{D}}^{\prime}$ phage}

$\mathrm{V}$, hydrated volume; $V_{d}$, volume without water; $M$, molecular weight; $K$, hydration; $Q$, degree of swelling.

$\begin{array}{lccccc} & \begin{array}{c}V \\ \left(10^{8} \AA^{3}\right)\end{array} & \begin{array}{c}V_{d} \\ \left(10^{8} \AA^{3}\right)\end{array} & \begin{array}{c}M \\ \left(10^{6}\right)\end{array} & \begin{array}{c}K \\ \left(\mathrm{~g} \mathrm{~g}^{-1}\right)\end{array} & Q \\ \text { Phage } & 2.2 & 1.2 & 110 & 0.55 & 1 \cdot 8 \\ \text { DNA } & 1.2 & 0.45 & 50 & 1.0 & 3 \\ \text { Protein } & 1.0 & 0.75 & 60 & 0.3 & 1.4\end{array}$

At this point we faced a very important problem: what is the conformation of DNA in phage heads and what is its secondary structure? To this effect we have measured the scattering intensity of phage gels in a range of angles from 5 to $20^{\circ}$. The experimental data for phage $S_{D}$ and the calculated curves (according to Bram, 1971) for various forms of DNA are presented in Fig. 6. Our experimental data are in good agreement with the theoretical curve for the B-form. It ought to be noted that the interpretation of scattering curves in this range of angles is not a simple task for there is a possibility of mutual interference between DNA and the protein part of the phage.

\section{References}

Boyarintseva, A. K., Dembo, A. T. \& Feigin, L. A. (1973). In Molecularnaya biologiya virusov (Sbornik trudov), pp. 93-97. Moscow: Institute of Virology, Academy of Medical Sciences.

Bram, S. (1971). J. Mol. Biol. 58, 277-288.

Gordon, C. N. (1972). J. Mol. Biol. 65, 435-445.

Kiselev, N. A., Tikhonenko, T. I., Kaftanova, A. S. \& KiseleV, F. L. (1963). Biokhimiya, 28, 1065-1069.

Kratky, O., Pilz, I. \& Schmitz, P. J. (1966). J. Colloid Interface Sci. 21, 24-34.

Luzzati, V., Nicolaeff, A. \& Masson, F. (1961). J. Mol. Biol. 3, 185-201.

Mittelbach, P. (1964). Acta Phys. Austr. 19, 53-102.

Nikol'skaya, I. I., Birkadze, T. V., Petrovskit, G. V. \& TiKhONENKo, T. I. (1972). Vopr. virusol. 6, 695-700.

Pilz, I. \& Kratky, O. (1967). J. Colloid Interface Sci. 24, 211-218.

Rol'bin, Yu. A., Kayushina, R. L., Feigin, L. A. \& ShCHEDRIN, B. M. (1973). Kristallografiya, 18, 701-709.

Sosfenov, N. I. \& FeIGIN, L. A. (1970). Apparat. metod. rentgenostrukt. anal. 7, 15-22.

Sosfenov, N. I., Feigin, L. A., Bondarenko, K. P., Goryunov, E. S., Manochkin, A. N., MirenskiI, A. V., Tereshchenko, I. P., Atapkov, N. K. \& Sadikov, A. A. (1969). Apparat. metod. rentgenostruktur. anal., 5, 53-72. Tikhonenko, T. I., Velikodvorskaya, G. A. \& Zemtsova, E. V. (1962). Biokhimiya, 27, 726-733.

\title{
X-ray Small-Angle Studies of the Pyruvate Dehydrogenase Core Complex from Escherichia Coli K-12
}

\author{
By H. DuRChSChLAG \\ Institut für Physikalische Chemie der Universität, Heinrichstrasse 28, A-8010 Graz, Austria
}

\begin{abstract}
The pyruvate dehydrogenase core complex from E. coli $K-12$, defined as the multi-enzyme complex which can be obtained with a unique polypeptide chain composition, has been investigated in solution with the X-ray small-angle technique. The molecular weight of the core complex of $3.78 \times 10^{6}$ Dalton verifies the ratio of polypeptide chains of 16:16:16 of the three enzyme components, pyruvate dehydrogenase ( $E C$ 1.2.4.1), dihydrolipoamide transacetylase ( $E C$ 2.3.1.12), and dihydrolipoamide dehydrogenase ( $E C$ 1.6.4.3), present in the complex. In connexion with the values obtained for the radius of gyration $(156.5 \AA)$, volume $\left(1.07 \times 10^{7} \AA^{3}\right)$ and amount of solvent associated with the complex $(1.03 \mathrm{~g} / \mathrm{g})$ a loose packing of subunits in the complex has to be assumed. Additional information about that can be derived by determination of specific inner surface $\left(7 \cdot 1 \times 10^{-2} \AA^{-1}\right)$, mean transversal length $(56.6 \AA)$, and coherence length $(123.5 \AA)$ as structural parameters. Fourier transformations of scattered intensity and of structural amplitude have been carried out and show the existence of slightly disturbed spherical symmetry of the complex built up from subunits. The mean diameter of the three different subunits of about $78 \AA$ and the maximum diameter of the complex of $433 \AA$, as determined from the correlation function, corroborate the large extension of the complex. The comparison of experimental and theoretical scattering curves reveals the structure of the complex. Although not representing a unique solution, a lot of model calculations indicate the complex to be arranged from morphological rather than functional subunits. At each edge of a cubic centre, formed by dimer transacetylase components, dimer pyruvate dehydrogenase and dimer flavoprotein components are arranged according to the best fit. Far-reaching conformity between experimental results and model was established.
\end{abstract}

